\title{
THE NEED FOR REFORM IN TURKISH TAX SYSTEM: MAIN PROBLEMS AND RECOMMENDATIONS
}

\begin{abstract}
Adnan GERÇEK ${ }^{1}$
Abstract

Although their form and purpose vary between countries, tax systems are of great importance in terms of developing the country, increasing investments and ensuring efficiency in resource allocation. For this reason, the necessary changes and reforms have been made in the tax system. Until today, several fundamental reforms and amendments have been made to make the Turkish tax system a modern tax system. As a result of these frequent changes, today's tax system has become extremely complex, unfair and unefficiency. In the Turkish tax system, source theory is essential in the definition of income. Therefore the tax base is limited, the number of taxpayers is low, and the informal economy is widespread. As a result of all this, frequent tax amnesties comes to the agenda in Turkey and the tax system is into a "vortex of failure".

To make the Turkish tax system simpler, more comprehensible and effective, the "New Generation Tax System" should be created. The following reforms should be made in this process: the basic tax laws should be rewritten, and the net accretion theory should be accepted to make the tax system simple, understandable and justified. In addition, in order to implement the tax system in an efficient manner, the tax administration and tax audit restructuring should be completed.
\end{abstract}

Keywords: Tax system, Tax amnesty, Minimum subsistence allowance, Tax reform, Tax administration.

JEL Code: H2O, H21, H24.

\section{Introduction}

Tax reform is defined as the fundamental changes and improvement movements made to achieve the objectives like the simplification of the tax system, efficiency, justice, etc. Basic changes are needed in order for the tax system to keep up with developments in economy and technology. For this reason, changes in tax laws have always been on the agenda. However, many changes in the tax system are not the reform but rather revisions.

Although there are frequent changes in the Turkish tax system, there is no significant improvement in taxation. This is because the problems accumulated in the Turkish tax system have become so that it is not possible to overcome them with minor revisions. Therefore, a radical reform in the Turkish tax system has become inevitable.

The aim of this study is to identify the main problems that exist in order to reveal the need for reform in the current Turkish tax system and to develop suggestions for their solution. For this, we primarily provide information about basic reforms in Turkey and then we reveal the underlying problems in the Turkish tax system today. Considering that the Turkish tax system has fallen into the vortex, reform proposals have been presented to solve the problems.

\footnotetext{
1 Prof. Dr., Bursa Uludağ University, Faculty of Economics and Administrative Sciences, Department of Public Finance, Turkey, agercek@uludag.edu.tr
} 


\section{Fundamental Reforms in Turkish Tax System}

Significant changes in taxes are defined as tax reform, while others are considered revision (Jha, 2010: 384). From this perspective, the Turkish tax system has undergone several major tax reforms and many revision processes. After the abolition of tithe in 1925 and the dividend tax replacing with profit tax in 1926, the first fundamental tax reform process in Turkey started. The changes which were the foundations of today's modern Turkish tax system and the second major reform were made in 1950. In 1961, serious revisions were made; significant changes have been made by rewriting the Income Tax Law and Tax Procedure Law (Varcan, 1993: 144).

Following the liberal policies implemented after 1980, an important reform was realized with the inclusion of VAT in our tax system in 1985 and this process continued with the SCT that came into force in 2002. In the period that beginning with the implementation of VAT and continuing with acceptance of SCT is an important step to adapt to the EU harmonization process (Demirli, 2011: 285). Besides, corporate tax law was rewritten to adapt to the global world and became applicable in 2006.

\section{Major Problems of Turkish Tax System}

\subsection{Low Tax Capacity and Tax Effort}

A major problem of the Turkish tax system is the low tax capacity and low tax effort. In the context of the registered economic activities, it is seen that the tax effort in our country between the years of 2007-2018 ranged from 0.86 to 1.10 . When in Turkey the informal economy is assumed to be $25 \%$ of GDP, the tax effort is decreasing and takes place between 0.69 and 0.88 .

\subsection{Low Tax Base and Number of Taxpayers}

One of the main problems of the Turkish tax system is the low tax base and the low number of taxpayers paying tax through the tax return. From 1990 until today, Turkey's population increased by about $52 \%$. There was almost no increase in the number of income taxpayers. This is a clear indication that the tax base in our country is not expanding. The ratio of the active income taxpayers to a total number of populations in Turkey is only 2.3\% (OECD, 2017: 77).

\subsection{Complexity of Tax System}

Although many changes have been made under the name of reform in the Turkish tax system; instead of providing justice, simplicity, generality, stability and efficiency, it has further complicated the system. Due to exemption, exception, and discounts in Turkey, approximately $24 \%$ of total tax revenues are waived (Hazine ve Maliye Bakanlığı, 2018: 285). The legal complexity of the Turkish tax system is low, but its operational complexity is higher than in the developed countries (Budak \& James, 2018). Turkey has the world's most complex tax and accounting system (TMF Group, 2017). 


\subsection{High Share of Indirect Taxes}

In the EU and OECD countries, $67 \%$ of tax revenues are collected from direct taxes and $33 \%$ is collected from indirect taxes (OECD, 2018: 9-11). In Turkey, the opposite result of the implementation of tax laws, they come across a similar tax structure. For example, $32 \%$ of tax revenues collected is expected to be collected in the 2019 budget from direct taxes, and $68 \%$ is expected to be collected from indirect taxes (BÜMKO, 2019: 68). The main reason for the high share of indirect taxes in Turkey is not the high rates of indirect tax, but that the direct tax revenues are not sufficient.

\subsection{Removing Frequent Tax Amnesty Laws}

Frequent use of the tax amnesty in Turkey, creating a negative impact on tax compliance and encourage tax evasion attempts of the taxpayers (Andreoni, 1991: 144). A total of 37 tax amnesty laws have been enacted under different names in our country. Tax annuities, which are made on average every two-three years, place taxpayers in the expectation of a new amnesty law. Thus, our country is almost caught in the vortex of tax amnesty and as a result, the tax system has become almost helpless, inconclusive and ineffective.

\subsection{Adoption of Taxation by Resource Theory}

It can be said that the taxation based on the source theory is the basis of many problems in the field of taxation in Turkey. Source theory narrows the taxation area and tax base, decreases tax revenues, ignores the principle of justice in tax, leads to the spread of informal economy and cannot tax new incomes of economic life (Arıkan \& Inneci, 2016: 14).

\subsection{Lack of Sufficient Tax Security Institutions in the Tax System}

In previous periods in our country; tax security institutions such as precedent and wage, wealth declaration, average profit rate, minimum gross revenue, standard of living standard, tax return to wage earners have been applied (Şanver \& Oktar, 2013: 3). However, these tax security institutions were later abolished and there is no tax security institution in the income tax (except for the equivalent rental price).

\subsection{Implementation of Principle of Administration instead of the Principle of Legality in Taxation}

The principle of legality is valid in taxation. Therefore, according to the article 73/4. of the Constitution, the President may make arrangements regarding the exemption, exceptions, discounts, and rates within the limits determined by the law. The frequent use of this power leads to the spread of the principle of administration in taxation (Gerçek \& Bakar, 2017: 23). In addition, regulations, general communiqués, circulars and even specialties in our country and new regulations or rules that are not in the laws regarding taxation are undermining the principle of certainty in taxation. 


\subsection{Unfinished the Restructuring of Tax Administration}

In 2005, the revenue administration was restructured with the creation of the Revenue Administration. However, a holistic central-regional-local organization has not been fully achieved (Gerçek, 2009: 28). On the other hand, although Tax Audit Board was established in 2011, the distinction between tax inspectors continued. In addition, the tax audit, which is the most important function of modern tax administrations, has been taken from the revenue administration with the establishment of the Tax Audit Board (Gerçek, 2011: 35).

\section{Reform Recommendations Regarding Turkish Tax System}

\subsection{Create a Modern and Efficient Tax System that Gives Value to Taxpayers}

A basic tax reform is needed to ensure that the Turkish tax system operates in a modern and effective manner. A "New Generation Tax System" should be established and a "Taxation Mobilization" should be announced to create a modern and effective tax system that values the taxpayer. In this process, the basic tax laws should be rewritten to cover the principles, institutions, and practices that the modern tax systems should bear.

\subsection{Tax System should be Made Simple, Understandable and Applicable}

In order to make the tax system simple, understandable and feasible, the tax laws must comply with the principles of modern taxation and respect taxpayer rights. In addition, the tax system should include tax security measures to prevent the informal economy. In addition, the implementation of some non-contemporary and inefficiency taxes should be terminated or included in other taxes.

\subsection{The Net Accretion Theory should be accepted for Expanding the Tax Base}

The most important step in the expansion of the tax base is to accept the net accretion theory instead of the source theory in the definition of income. The net increase theory, which takes into account the power of payment in taxation, extends the concept of income broadly, accepts all kinds of income and any value increase as income and thus provides better tax justice (Arıkan \& İnneci, 2016: 15).

\subsection{Pay Attention to Unitary Taxation in Income Tax}

In order to establish an effective tax system in Turkey, the unitary tax system should be focused on. Withholding taxation should be considered as a preliminary taxation of unitary taxation, not as final taxation, and thus the principle of taxation according to financial power should be implemented. Therefore, it should be ensured that agricultural earnings, all wages, capital goods and capital market instruments are taxed through an annual declaration.

\subsection{The Minimum Subsistence Allowance should be considered in Income Tax}

To ensure fairness in taxation a minimum subsistence allowance should be applied according to the person's civil and family situation in the income tax. While the minimum living allowance 
amount is determined, minimum living allowances applied in other countries and minimum wage applied in these countries, national income per capita etc. factors may also be considered.

\subsection{Powerful Auto Control Mechanism should be Established in Income Tax}

In order to prevent tax losses and leakages in Turkey, instead of determining the method of earnings on the basis of activity, as in many developed countries, the method of determination of earnings on the basis of wealth should be started. With this method, determination of earnings will be simplified and control will be easier. However, corruption, informality, abuse and nepotism will be prevented.

\subsection{The Number of Exemptions and Exceptions in Tax Laws should be reduced}

In order to create the perception that the Turkish tax system is fair, the number of exemptions and exceptions in the tax law should be reduced, so that the tax system should be made simple and understandable and the tax base should be expanded. With the implementation of minimum living allowance, exemptions and exceptions provisions which should be protected for special purposes should be written under the section of the relevant income element and the laws should be made more systematic and understandable.

\subsection{Taxation of Rant Revenues in Cities should be Ensured}

In our country, the increase in the value of real estates obtained from evaluated within the concept of the urban rant, taxation of real estates will be a very fair regulation. For this reason, it should be ensured that the appreciation gains in real estates within ten years have been declared and taxed after the de-inflation.

\subsection{Revision of Revenue Administration and Tax Audit should be Completed}

In order to complete the restructuring of the remaining income administration in our country, the central-regional-tax office model should be started as soon as possible. On the other hand, in order to carry out the tax audit, which is the most important function of the revenue administration, the tax audit units should be organized within the Revenue Administration. Thus, it should be ensured that all functions of taxation are carried out under a single roof in accordance with the understanding that "it is not possible to separate the meat from the bone".

\section{Conclusion}

Turkish tax system has reached today's structure as a result of many changes. As a result of all the reforms and revisions made to adapt to the conditions of the day, our tax system faces many problems. Some of these problems can be stated as follows: the narrow tax base and low number of taxpayers, complexity of tax system, high share of indirect taxes, frequent tax amnesty laws, the adoption of taxation according to the source theory, the lack of tax security institutions in the tax system, implementation of principle of administration instead of the principle of legality in taxation, and unfinished the restructuring of tax administration. 
In order to ensure the modern and efficient functioning of the Turkish tax system, there is a need for a basic tax reform rather than minor changes. With this tax reform, it should create a modern and effective tax system that values the taxpayers. For this, the perspective on taxation should be changed and the basic tax laws should be rewritten with the understanding of the "New Generation Tax System". In this process, the tax system should be made simple, understandable and feasible, the net accretion theory should be accepted instead of the source theory, and the number of exemptions and exceptions in tax laws should be reduced. In addition, income tax should be focused on unitary taxation, a minimum subsistence reduction should be implemented and a strong auto control mechanism should be established. In order to implemented tax system effectively and efficiently, the tax administration and tax audit restructuring in our country should be completed.

To make all these changes in the tax system, a strong political will and a "Taxation Mobilization" in Turkey should be declared. However, it is inevitable to make this basic reform so that the tax system gets rid of the vortex it has fallen into and can be implemented in a modern, effective and efficient manner.

\section{References}

Andreoni, J. (1991). "The Desirability Of A Permanent Tax Amnesty", Journal of Public Economics, Norlh-Holland.

Arıkan, Z. \& İnneci, A. (2016). "Vergilendirilebilir Gelir ve Gelir Vergisinde Üniter Yapıyı Bozan Uygulamalar", Sosyoekonomi, Vol. 24, No 30, ss. 11-28.

Budak, T. \& James, S. (2018). "The Level of Tax Complexity: A Comparative Analysis Between the UK and Turkey Based on the OTS Index", International Tax Journal, Vol.18, pp. 28-40.

BÜMKO, (2019). 2019 Yılı Merkezi Yönetim Bütçe Kanunu Teklifi ve Bağlı Cetveller, http://www.bumko.gov.tr/Eklenti/11291,2019mybkteklificetvellerpdf.pdf?0\&_ tag1=D8EEE19AD432DB9D48CC647916A050E3CB804DAF, (13.02.2019).

Demirli, Y. (2011). Gelişmekte Olan Ülkelerde Vergi Reformları ve Türkiye'de Gelir Üzerinden Alınan Vergiler Açısından Değerlendirme, Ankara, Maliye Bakanlığı Strateji Geliştirme Başkanlığı Yayını.

Gerçek, A. \& Bakar, F. (2017). “Vergilemede Kanunilik İlkesi Açısından Anayasa'nın 73/4. Maddesi ile Bakanlar Kuruluna Yetki Verilmesinin Değerlendirilmesi", International Journal of Public Finance, C. 2, S. 1, pp. 7-26.

Gerçek, A. (2009). “Gelir İdaresinin ve Vergi Denetiminin Yeniden Yapılandırılması: Dünü, Bugünü ve Yarını", Vergi Sorunları, S. 254 (Özel Ek).

Gerçek, A. (2011). "Vergi Denetim Birimlerinin Birleştirilmesi ve Sonuçları", Yaklaşım, Yıl. 19, S. 224, ss. 31-36.

Hazine ve Maliye Bakanlığı, (2018). Vergi Harcamaları Raporu, Ankara, Hazine ve Maliye Bakanlığı Gelir Düzenlemeleri Genel Müdürlüğü.

Jha, R. (2010). Modern Public Economics, Second Edition, New York, Routledge. 
OECD, (2017). Tax Administration 2017: Comparative Information on OECD and Other Advanced and Emerging Economies, Paris, OECD Publishing.

OECD, (2018). Revenue Statistics 2018: Tax revenue trends in the OECD, https://www.oecd.org/ tax/tax-policy/revenue-statistics-highlights-brochure.pdf (13.02.2019).

Şanver, C. \& Oktar, A. (2013), "Gelir Üzerinden Alınan Vergilerde Vergi Güvenlik Önlemleri ve Mükelleflerin Ba-Bs Bildirimlerine Bakışı Araştırması", Siyaset, Ekonomi ve Yönetim Araşttrmaları Dergisi, Yıl 1, C.1, S. 3, ss. 1-23.

TMF Group, (2017). The Financial Complexity Index 2017, https://www.tmf-group.com/ en/ news-insights/publications/2017/financial-complexity-index-2017/, (12.02.2019).

Varcan, N. (1993), Maliye Tarihi, Eskisehir, Birlik Ofset. 